\title{
Awakening or Enlightenment? On the Significance of bodhi
}

\author{
Bhikkhu Anālayo ${ }^{1}$
}

Accepted: 7 April 2021 / Published online: 6 May 2021

(C) The Author(s) 2021

\begin{abstract}
The central goal of traditional mindfulness practice is bodhi, often translated as "awakening." A critical examination of arguments proposed by Bhikkhu Bodhi in support of the alternative rendering as "enlightenment" confirms the preferability of understanding bodhi to refer indeed to a form of "awakening" as a way of conveying that the chief purpose of Buddhist mindfulness practice is to lead to realizing a liberating form of insight.
\end{abstract}

Keywords Awakening $\cdot$ bodhi $\cdot$ Buddha $\cdot$ Enlightenment $\cdot$ Nirvana

The overarching concern informing the cultivation of mindfulness in its ancient Indian setting was progress toward bodhi (Anālayo 2020). The relevant textual sources describe four distinct levels of such progress, from the attainment of stream entry to becoming an arahant/arhat (Anālayo 2021). The same texts tend to employ the term bodhi in particular to gaining the highest of these four levels, considered to correspond to the complete eradication of all defilements from the mind of the practitioner.

The Buddha's experience of Nirvana as the key element of his own realization of bodhi forms the starting point for the entire early Buddhist approach to truth and valid pathways to knowledge (Dhammadinnā 2021, p. 102). It is, after all, due to his experience of "bodhi" that the "Buddha" came to be socalled, the two terms being derivatives of the same etymological root budh. Hence, it is a matter of considerable consequence how to translate and understand the significance of the term bodhi.

Although there seems to be a general trend among scholars to favor the translation "awakening" (Anālayo 2021), in a detailed article dedicated to this topic, the eminent Pāli translator Bhikkhu Bodhi (2020) provided several arguments in support of the alternative translation "enlightenment." His conclusion relies on three main arguments (p. 76). One is that, according to his assessment, the English term awakening

Bhikkhu Anālayo

1 Barre Center for Buddhist Studies, 149 Lockwood Road, Barre, MA 01005, USA conveys more the sense of a "flash of insight or a sudden shift in level of consciousness," whereas enlightenment rather carries the sense of "a profound act of understanding with a comprehensive range." The second argument is that verb forms derived from the same etymological root as bodhi convey the sense to know directly, to understand, and to realize. The third argument draws on metaphors and similes that involve light and radiance, making enlightenment in his view the preferable translation.

\section{A Flash of Insight}

Regarding the first argument, Bodhi (2020, p. 60) illustrated his position with a metaphor that describes turning on the light after one has woken up, in that "by attaining arahantship, one turns on the light, flooding the mind with liberating knowledge, with 'enlightenment,' just as the electric light illuminates the room." The illustration provided in this way could be contrasted with an imagery of insight leading to the realization of Nirvana, which employs precisely the opposite imagery: the extinction of a lamp.

One should thoroughly examine the Dharma and insightfully discern its meaning with wisdom; liberation of the mind is like the quenching (= Nirvana) of a lamp. (AN 7.3: yoniso vicine dhammaṃ, pañ̃̃ayattham vipassati, pajjotass' eva nibbānam, vimokkho hoti cetaso). 
Although the metaphor employed here could in principle also refer to the passing away of an arahant (this is the reading adopted by the Pāli commentary Mp IV 1), the context makes such an interpretation rather improbable. In early Buddhist thought, "liberation of the mind" is attainable while still alive and not, contrary to some conceptions of liberation in the ancient Indian setting, something that happens only at death. Therefore, a considerably more straightforward interpretation is that the imagery of the Nirvana of the lamp intends the breakthrough to the experience of Nirvana. This, in turn, corresponds to the first meaning listed in the Pali-English Dictionary for the term nibbāna: "the going out of a lamp or fire" (Rhys Davids \& Stede 1921/1993, p. 362). The corresponding entry in the Dictionary of Pāli by Cone (2010, p. 580) similarly begins by listing the meaning "the ceasing to burn, going out," followed by providing precisely the description of the going out of a lamp (pajjotass' eva nibbānam) as an illustration. In a monograph study of Nirvana, Collins $(1998,191)$ took up the image of the quenching of a fire right at the outset of his exploration of "the imagery of Nirvana." The pride of place given in this way by different scholars aptly reflects the importance of the image in the passage translated above.

According to the Ariyapariyesanā-sutta and its parallel, when describing the successful achievement of his quest for liberation, the Buddha spoke of this in terms of his attainment of Nirvana, conveying thereby that this must indeed have been a key aspect of his bodhi (MN 26: nibbānam ajjhagamam and MĀ 204: 得 ... 涅槃). An experience of Nirvana involves a cessation of all links of dependent arising and thereby the cessation of conceptual types of knowledge as well as of any kind of inner vision of light, be it externally or internally generated, understood metaphorically or intended in a literal sense. In contrast, as noted by Kapstein (2004, p. 268), religious experiences of light or luminosity in general are clearly a distinct

class of religious experience which do engage the senses and are thus amenable to phenomenological description in sensorial terms, at least in large part; experiences of light may be euphemistically described as "ineffable" in order to accentuate their magnificence, but they are certainly not contentless. What is more, in the case of light, it is not merely a sensory phenomenology that concerns us; for in many cases, the physical perception of light is literally intended.

In contrast, Nirvana is the cessation of the six sense spheres and therefore not something that engages the senses. In fact, the early discourses tend to associate inner experiences of light or radiance rather with the cultivation of higher levels of mental tranquility (Anālayo 2017). As illustrated by the narrative of the Buddha's own pre-awakening cultivation of profound levels of mental tranquility, from an early Buddhist perspective such light-related meditative experiences fall short of being the final goal.

In fact, Bodhi (2020, p. 59) did consider the term awakening to be at least appropriate for the first experience of Nirvana with stream-entry as a "sudden breakthrough to the truth of the Dhamma." The early discourses usually describe such breakthrough in terms of the arising of the Dharma-eye. Although not being an image "of waking up from sleep but the opening of an eye, this gain of the Dhamma-eye might reasonably be described as an awakening" (p. 60). Given that the Buddha did not attain stream-entry but right away full awakening, it could be argued that the same sense of a sudden breakthrough to the unconditioned, comparable to opening an eye, would also be appropriate for the Buddha's bodhi.

\section{Knowledge or Light}

The second argument in support of the translation "enlightenment" is that verbs derived from the root budh can often convey a sense of "understanding" or "knowledge." This is meant to counter the position taken by Norman $(1990$, p. 26$)$ that "the root budh- which underlies these words has no direct connection with 'light.' The root means literally 'to wake up,' or metaphorically 'to wake up (to a fact), to know it.."

The quote already shows that the meaning of budh as a form of understanding or knowledge is not being contested. This is evident not only from the fact that Norman (1990, p. 26) explicitly speaks of "to know" in the above quote but also from the translations used by the same author elsewhere. An example in case is a verse noted by Bodhi $(2020$, p. 65) as one of several examples where "to translate bujjhati as 'awakens,' though possible, would strain ordinary English usage. Here, the sense of 'directly knows, understands, realizes' is far more natural and appropriate." Norman (1997/2004, p. 20) indeed translated the relevant part of the verse (Dhp 136: bālo na bujjhati) as "the fool does not know [this]," corresponding verbatim to the translation proposed by Bodhi (2020, p. 64). This gives the impression that the argument presented by the latter appears to be based on a misunderstanding of the position of the former. The point at issue is not that the translation "to awaken" should invariably be imposed on all possible derivatives of the root budh without allowing the alternative of adopting renderings like "to know," "to understand," or "to realize." The question much rather concerns identifying the nuances of meaning that derivatives from this root convey in addition to understanding and knowledge.

Relevant verb forms that combine budh with a prefix can, as noted by Bodhi (2020, p. 65), at times indeed convey a sense of awakening from sleep. One example that is supported by a parallel version is a description of having dreams that will 
no longer be seen when waking up (MN 54: pațibuddho, MĀ 203: 悟). Another example occurs in verse:

They are asleep and do not wake up; it is time for them to wake up.

(SN 1.7: suttā te na pabujjhanti, kālo tesam pabujjhitun ti).

On their own they do not awaken from sleep, for long their mind is bereft of the ability to wake up.

(SĀ 579: 睡眠不自覺, 長劫心能悟; the combination 長劫 usually renders kalpa, which in the present case seems less apt, as the context requires the pada to carry a negative sense).

This is called being asleep and not waking up; at some time they must get to wake up.

( $\mathrm{SA}^{2}$ 164: 是名睡不䠽, 有時必得䠽).

Another example involves the Buddha being challenged for sleeping at dawn, after a night spent in meditation. Bodhi (2020, p. 73) commented on the Buddha's reply to this challenge that "it is possible the Buddha is saying that as an Awakened One, who has eliminated all attachments, he is entitled to sleep after sunrise," although such an interpretation "may be reading more into the verse than is intended." Here is the Pāli version, and one of its Samyukta-ăgama parallels (the Buddha's reply in another parallel, $\mathrm{SA}^{2} 26$, proceeds differently and has neither a reference to sleeping nor to the "Buddha"):

The Buddha sleeps, what is that to you?

(SN 4.7: budho soppati kin-tav-ettha?).

The Buddha just gets ease from sleep.

(SĀ 1087: 唯佛得安眠).

The idea of a word play does seem to be a viable interpretation, in that the status of being an awakened one has no bearing on whether one still goes to sleep. This contrasts with notions current in ancient India that a fully realized sage is beyond sleep.

Whatever may be the last word on this particular instance, it seems clear that derivatives of the root budh can carry a sense related to awakening. Such a sense is already attested in the Rgveda (1.137.2: utá vām uṣáso budhí sākám súryasya raśmíbhih), where budhí conveys the sense of the awakening of dawn. In a monograph study of the terminology employed in the Rgveda, Grassman $(1955$, p. 907) explained that the foundational meaning of budh is to wake up and to be awake ("Grundbegriff is "erwachen, wachen"'), out of which other meanings developed. From the viewpoint of ancient
Indian precedents to Buddhist usage, the meaning of awakening appears to have been fairly central and it is quite probably this centrality that underlies the argument presented by Norman (1990) and others.

In contrast, as duly noted by Bodhi (2020, p. 69) himself, "the root budh and the words derived from it in no way denote the ideas of 'light' or 'illumination'." It would follow that, when choosing between the two alternative renderings of bodhi, preference should be given to the one that captures the nuance of awakening in addition to the main sense of a form of understanding or knowledge.

\section{Light Imagery}

Evaluating the third argument, which adduces imagery of light and radiance in support of the translation "enlightenment," requires distinguishing between the actual experience of bodhi and the function of the Buddha or his awakened disciples as teachers in the world. An example relevant to this distinction is the observation by Bodhi (2020, p. 70) that, after the Buddha had given his first sermon,
"a measureless great radiance appeared in the world, sur- passing the divine majesty of the gods." This again sug- gests light as the most fitting symbol for the perfect sambodhi of the Buddha. In fact, another sutta tells us that such a "measureless great radiance" occurred along with his attainment of sambodhi itself (at AN II 131, ${ }_{15-16}$ ).

The same discourse associates such a light phenomenon also with the Buddha's conception in his mother's womb and with the occasion of his birth (AN 4.127). It follows that the great radiance is not a specific illustration of his bodhi. Instead, it is rather something believed to have happened on several extraordinary occasions in the Buddha's life. The case of the Dhammacakkappavattana-sutta thereby exemplifies the need to discern between awakening and subsequent teaching activity.

Early discourses from different transmission lineages agree in granting in principle that someone could become a Paccekabuddha/Pratyekabuddha, a "Buddha" who does not teach (Anālayo 2010 and 2015). This shows that the notion of bodhi, at least in the type of texts that reflect the earliest strata of Buddhist thought, did not include teaching activity as a necessary component. It would follow that light imagery related to teaching activity is not directly relevant to assessing the best way of translating the term bodhi, which is not necessarily about becoming a teacher.

Another example provided by Bodhi (2020, p. 69) relates to the three higher knowledges attained by the 
Buddha, where "the acquisition of each knowledge is depicted by the image of light dispelling darkness." Yet, the first two of these three knowledges have no bearing on bodhi and can according to the early discourses be attained by anyone who has gained sufficient tranquillity of mind, without a need for cultivating liberating insight. In early Buddhist thought, even a single past life need not be recollected in order to gain full awakening (Anālayo 2007, p. 100). This holds not only for disciples but also for Buddhas, as the reports of the awakening of the former Buddha Vipassin/Vipaśyin do not refer to the first two higher knowledges (Waldschmidt 1956, p. 146), showing that these were not considered a requirement for becoming a Buddha. Again, imagery of light related to the three higher knowledges is not specific to the event of bodhi.

Two additional examples provided by Bodhi (2020, p. 70) concern an illustration of the Buddha's insight into dependent arising as comparable to the "sun lighting up the sky" and a qualification of the teaching given in the Buddha's first sermon, according to which "the eye arose in me, knowledge arose, wisdom arose, clear knowledge arose, light arose." Regarding the former, it needs to be noted that this occurrence (Ud 1.3) is only one of three alternative verses, the other two of which do not involve any light or sun imagery (Ud 1.1 and Ud 1.2). Similarly, among the counterpart verses in the Udānavarga extant in Sanskrit, only two out of eight verses have light imagery (Uv 33.81-82, in contrast to Uv 33.76-80 and Uv 33.83). This conveys the impression that the light imagery could be less central to this episode than it may seem at first sight.

In the case of the Buddha's first sermon, a reference to the arising of light also occurs in a discourse parallel in the Ekottarika-āgama (EĀ 24.5: 光生), a discourse extant in Tibetan (D 31 or P 747: snang ba bskyed pa; see also Skilling, 1993, p. 194), and in the Mahāvastu (Marciniak 2019, p. 424: ālokam prādurabhūși). A range of other parallels to the Dhammacakkappavattana-sutta, found among the early discourses, discourse quotations, and Vinayas, have otherwise similar listings but without a reference to light:

Vision arose, knowledge, understanding, and realization arose.

(Waldschmidt 1952, p. 146: cakșur udapādi jñānam vidyā buddhir udapādi).

Vision arose, knowledge, understanding, and realization arose. (Wogihara 1936/1971, p. 579: cakșur udapādi jñānam vidyā buddhir udapādi).

Vision arose, knowledge, understanding, realization, and comprehension arose.
(Chung 2006, p. 86: mig skyes so, shes pa dang, rig pa dang, blo dang, rtogs pa skeys so.

Vision arose, knowledge, understanding, and realization arose.

(Up 6056: mig skyes so, shes pa dang, rig pa dang, blo skyes so).

Vision, knowledge, understanding, and realization arose.

(SĀ 379: 生眼, 智, 明, 覺).

I experienced vision, experienced meditative concentration, experienced wisdom, and experienced realization, which made my mind attain understanding.

( $T$ 109: 受眼, 受禪, 受慧, 受覺, 令意得解; which is one of several slightly different listings, none of which has a reference to light).

I was able to arouse vision, knowledge, understanding, and realization.

( T 100: 能生眼, 智, 明, 覺).

Vision arose, knowledge arose, understanding arose, realization arose, insight arose, and wisdom arose.

(T XXII 104c: 眼生, 智生, 明生, 覺生, 通生, 慧生; a previous instance at $104 \mathrm{~b}$ is shorter: 生眼, 智, 明, 覺).

Knowledge arose, vision arose, realization arose, understanding arose, insight arose, and wisdom arose.

(T XXII 788a: 智生, 眼生, 覺生, 明生, 通生, 慧生).

Vision arose, knowledge arose, understanding arose, and realization arose.

(T XXIII 448b: 生眼, 生智, 生明, 生覺).

I attained the arising of pure wisdom, vision, knowledge, understanding, and realization.

(T XXIV 127c: 得淨慧, 眼, 智, 明, 覺生).

Being concentrated I was able to give rise to vision, knowledge, understanding, and realization.

(T XXVI 479b: 定能發生眼, 智, 明, 覺).

The absence of a mention of light holds for the Catușparișat-sūtra, a discourse quotation in the Abhidharmakośavyākhyā, a discourse extant in Tibetan and a discourse quotation in the Abhidharmakośopayyikā-țik $\bar{a}$ in the same language, a Samyukta-ăgama discourse and two individual discourses extant in Chinese translations, versions of the Buddha's first sermon found in the Chinese translations of the Vinayas of the Mahissāsaka (T 1421), Dharmaguptaka (T 1428), Sarvāstivāda (T 1435), and Mūlasarvāstivāda 
traditions ( $\mathrm{T}$ 1450), and a discourse quotation in the Chinese translation of the Dharmaskandha (T 1537). Clearly, light is not a common element among descriptions given in parallel versions of what according to tradition was the first teaching given by the Buddha.

Even the versions that compare the Buddha's insight into dependent arising to the sun lighting up the sky, or his insight into the four truths to the arising of light, are specific to his case and do not seem to be directly applicable to the notion of bodhi in general. Take the case of mindfulness as the first of seven factors of bodhi (bojjhanga/bodhyanga/ 支/byang chub kyi yan lag). This is indubitably a mental quality not confined to those who wish to become Buddhas. Instead, it is relevant for all disciples who aspire to reach freedom from defilements. Achieving the goal of such aspirations does require insight into dependent arising and the four truths, but such insight follows in the footsteps of the Buddha's original discovery. In contrast, the instances of light imagery just mentioned serve to express the element of discovery made by the Buddha, who reached bodhi on his own and then shared his discovery with others by engaging in teaching activity.

It seems that items like the seven factors of bodhi need to be rendered in a way that does justice to what is common to the bodhi of Buddha(s) and of their disciples, which is of course the experience of Nirvana resulting in the destruction of defilements. The term Nirvana, as noted above, conveys the opposite of the idea of an arising of light. This fundamental metaphor needs to be kept in mind when considering the implications of the event of bodhi as understood in the thought world of the early discourses.

Besides, another problem becomes evident in the following comment by Bodhi (2020, p. 54 n. 4), regarding connotations of the term enlightenment "to describe the European intellectual movement of the eighteenth century. I don't see this as at all problematic, for our minds can easily separate the two spheres of reference." Yet, according to McMahan (2008, p. 18)

the most common English translation, "enlightenment," invokes, however, a complex of meanings tied to the ideas, values, and sensibilities of the European Enlightenment: reason, empirical observation, suspicion of authority, freedom of thought, and so on. Early translators, moreover, consciously forged this link.

In other words, the employment of the translation "enlightenment" is considered indeed problematic, as it risks continuing an interpretative strategy employed to present Buddhism in a way palatable to Western sensitivities but which does not necessarily do justice to the early Buddhist textual sources. This alone would already make it preferable to avoid such translation choice.
In sum, then, the Buddha's bodhi can be understood to involve a sudden shift in level of consciousness due to the realization of Nirvana, equaling the cessation of the six sense spheres. References to this event with derivatives of budh convey the sense of an understanding or knowing that comes with a secondary nuance of waking up. Metaphors and similes that involve light and radiance tend to portray the Buddha's teaching activities and their repercussions rather than the actual breakthrough to what is, after all, best rendered as his "awakening."

Acknowledgements The author is indebted to Bhikkhu Bodhi and Bhikkhunī Dhammadinnā for commenting on a draft version of this article.

Funding Open Access funding enabled and organized by Projekt DEAL.

\section{Declarations}

Ethical Approval This article does not contain any studies performed by the author with human participants or animals.

Conflict of Interest The author declares he has no conflict of interests.

Abbreviations AN, Añguttara-nikāya; D, Derge edition; Dhp,

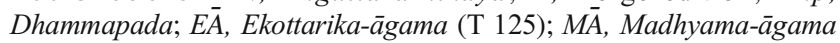
(T 26); MN, Majjhima-nikāya; Mp, Manorathapūrañī; P, Peking edition; SÁ, Samyukta-āgama (T 99); $S \bar{A}^{2}$, Samyukta-āgama (T 100); SN, Samyutta-nikāya; T, Taishō (Chinese Buddhist Electronic Text Association); Ud, Udāna; Up, Abhidharmakośopāyikā-țikā; Uv, Udānavarga

Open Access This article is licensed under a Creative Commons Attribution 4.0 International License, which permits use, sharing, adaptation, distribution and reproduction in any medium or format, as long as you give appropriate credit to the original author(s) and the source, provide a link to the Creative Commons licence, and indicate if changes were made. The images or other third party material in this article are included in the article's Creative Commons licence, unless indicated otherwise in a credit line to the material. If material is not included in the article's Creative Commons licence and your intended use is not permitted by statutory regulation or exceeds the permitted use, you will need to obtain permission directly from the copyright holder. To view a copy of this licence, visit http://creativecommons.org/licenses/by/4.0/.

\section{References}

Anālayo, Bh. (2007). The Vekhanassa-sutta and its Madhyamaaggama parallel: A case study in the transmission of the Pāli discourses. Journal of the Centre for Buddhist Studies, 5, 89-104.

Anālayo, Bh. (2010). Paccekabuddhas in the Isigili-sutta and its Ekottarika-āgama parallel. Canadian Journal of Buddhist Studies, 6, 5-36.

Anālayo, Bh. (2015). Pratyekabuddhas in the Ekottarika-āgama. Journal of the Oxford Centre for Buddhist Studies, 8, 10-27.

Anālayo, Bh. (2017). The luminous mind in Theravāda and Dharmaguptaka discourses. Journal of the Oxford Centre for Buddhist Studies, 13, 10-51. 
Anālayo, Bh. (2020) The qualities pertinent to awakening: Bringing mindfulness home. Mindfulness, doi: https://doi.org/10.1007/ s12671-020-01398-3.

Anālayo, Bh. (2021). The four levels of awakening. Mindfulness, 12, 831-840. https://doi.org/10.1007/s12671-020-01530-3.

Bodhi, Bh. (2020). On translating 'Buddha.' Journal of the Oxford Center for Buddhist Studies, 19, 52-78.

Chung, J. (2006). Dharmacakrapravartana-dharmaparyāya of the Sarvāstivāda and Mūlasarvāstivāda tradition. In U. Hüsken, P. Kieffer-Pülz, and A. Peters (ed.) Jaina-Itihāsa-Ratna, Festschrift für Gustav Roth zum 90. Geburtstag (pp. 75-102). Marburg: Indica et Tibetica.

Collins, S. (1998). Nirvana and other Buddhist felicities, utopias of the Pali imaginaire. Cambridge: Cambridge University Press.

Cone, M. (2010). A dictionary of Pāli, part II, g-n. Oxford: Pali Text Society.

Dhammadinnā, Bh. (2021). Reflections on truth and experience in early Buddhist epistemology. In C. Roloff, W. Weisse, \& M. Zimmermann (Eds.), Buddhism in Dialogue with Contemporary Societies (pp. 101-133). Münster and New York: Waxmann.

Grassman, H. (1955). Wörterbuch zum Rig-Veda. Wiesbaden: Otto Harrassowitz.

Kapstein, T. M. (2004). The presence of light, divine radiance and religious experience. Chicago: University of Chicago Press.

Marciniak, K. (2019). The Mahāvastu, a new edition, vol. III. Tokyo: International Research Institute for Advanced Buddhology at Soka University.
McMahan, D. L. (2008). The making of Buddhist modernism. New York: Oxford University Press.

Norman, K. R. (1990). Aspects of early Buddhism. In D. S. Ruegg \& L. Schmithausen (Eds.), Earliest Buddhism and Madhyamaka (pp. 24 35). Leiden: Brill.

Norman, K. R. (1997/2004). The word of the doctrine (Dhammapada). Oxford: Pali Text Society.

Rhys Davids, T. W., \& Stede, W. (1921/1993). Pali-English Dictionary. Delhi: Motilal Banarsidass.

Skilling, P. (1993). Theravādin literature in Tibetan translation. Journal of the Pali Text Society, 19, 69-201.

Waldschmidt, E. 1952. Das Catușparișatsūtra, eine kanonische Lehrschrift über die Begründung der Buddhistischen Gemeinde, Text in Sanskrit und Tibetisch, verglichen mit dem Pāli nebst einer Übersetzung der chinesischen Entsprechung im Vinaya der Mūlasarvāstivādins, auf Grund von Turfan-Handschriften herausgegeben und bearbeitet. Berlin: Akademie Verlag.

Waldschmidt, E. (1956). Das Mahāvadānasūtra, ein kanonischer Text über die sieben letzten Buddhas, Sanskrit, verglichen mit dem Pāli nebst einer Analyse der in Chinesischer Übersetzung überlieferten Parallelversion, auf Grund von Turfan-Handschriften herausgegeben. Berlin: Akademie Verlag.

Wogihara, U. (1936/1971). Sphuțārthā Abhidharmakośavyākhyā by Yaśomitra, Part II. Tokyo: Sankibo Buddhist Book Store.

Publisher's Note Springer Nature remains neutral with regard to jurisdictional claims in published maps and institutional affiliations. 